

Journal of Bioscience and Applied Research

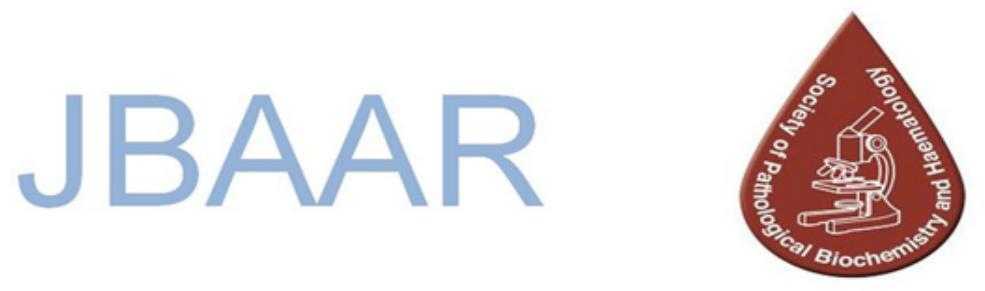

WWW.JBAAR.ORG

\title{
Pioneer Study on the Assessment of ground carbon content for species (Acacia seyal, Acacia sengal and Balanites aegyptiaca) using inventory data as Climate Change Indicators in Sudan
}

\author{
Osama B. Ali \\ The Deputyship of Quality and Academic Development, Department \\ of Studies and Information, Jazan University, Saudi Arabia \\ Corresponding author e.mail: osamabashir90@hotmail.com
}

\begin{abstract}
Sudan is vast country with diverse of ecological systems, however the contribution to climate within the global climate would be addressed remarkably for the situation of the on-going activity. The climate change and mitigation could be observed through forest inventory using volume of wood and the above ground carbon content of land cover. This study was carried out during the summer of 2012 at the Higlig Area south of Kordfan state near the borders with South .A sum total of 176 sample plots with radices $200 \mathrm{~m}^{2}$ cover area representing 196000 hectares. Each sample plot was marked on the map using the Global Positioning System (GPS) the position was detected any lay out took place. Each sample plot was measured by callipering all trees with diameter at breast height (dbh) $\geq 4$ $\mathrm{cm}(\mathrm{DBH})$ and tree number record with maximum number of 10 trees. The data led to classify forest types according to tree number per hectare to close forest, open wood land and scattered trees and shrubs, volume of each was calculated as $86180 \mathrm{~m}^{3}, 16065 \mathrm{~m}^{3}, 10394 \mathrm{~m}^{3}$ respectively and total of $112639 \mathrm{~m}^{3}$.The dry volume were changed to carbon content using the biomass expansion factor for tropical forests $(0.7975)$ so total of $296505 \mathrm{~kg}$ of carbon content for closed forest, $1892 \mathrm{~kg}$ carbon content for open forest and $721 \mathrm{~kg}$ for trees and shrubs with total of $299118 \mathrm{~kg}$ for the whole area, the carbon content expressed as carbon sink in the form of above ground carbon content, thus reflect towards climate change and mitigation as same would be carbon emission for other uses, any forest inventory should extracted those data to reflect the balance of above ground carbon in way of carbon sink or carbon emission.
\end{abstract}

Key word: Climate change, Mitigation, Carbon Content, Biomass, Closed Forest, Open Wood Land, Scatter Trees and Shrubs.

\section{Introduction}

Sudan is a vast country with an area of $1,886,068 \mathrm{~km}^{2}$. It lies between latitudes $10^{\circ}$ and $22^{\circ} \mathrm{N}$ and longitudes $22^{\circ}$ to $38^{\circ}$ E. Its landscape consists primarily of gently sloping plain, with the exception of Jebel Marra, Red Sea Hills and Nuba Mountains. Mean annual temperatures vary between $26^{\circ} \mathrm{C}$ and $32^{\circ} \mathrm{C}$ across the country. The northern part is almost desert and semi desert with average annual temperatures around $30^{\circ} \mathrm{C}$ and average annual rainfall of about $150 \mathrm{~mm}$. The central part is semi-desert to savannah with average annual temperatures around $27^{\circ} \mathrm{C}$, and average annual rainfall of about $200 \mathrm{~mm}$. Rainfall, which supports the majority of the agricultural activity, is erratic and increasing in amount southward. Sudan can be ecologically divided into five vegetation zones according to rainfall patterns from North to South. These are:

Desert: (0-75 $\mathrm{mm}$ of precipitation)

Semi-desert: $(75$ - $300 \mathrm{~mm})$

Low rainfall savannah on clay and sand: (300 - $500 \mathrm{~mm})$

High rainfall savannah: $(500-900 \mathrm{~mm})$

Montane Vegetation: (500 - $900 \mathrm{~mm})$

Sudan is endowed with a wide range of ecosystems and species diversity. The ecological zones extend over a wide range from the desert in the extreme north to the savannah. According to Land Cover Atlas of Sudan (FAO, 2012), 
forests and rangelands represent $35.6 \%$ of the total country area (Table 1 and Fig. 1).Sudan is rich in biodiversity within diverse environmental systems making it endowed with flora and fauna which are being threatened by natural factors and human activities.These factors include: Population growth and changes in demographic attributes (rural/urban balance, agricultural dependency, income, changes in aspirations and expectations such as greater interest in environmental issues); Economic growth (and related changes in personal wealth, prosperity and consumption patterns); Land-use change (particularly deforestation); Changes in social dimensions (including changes associated with cultural, ethnic, gender equity issues, changes in socio-political structures, and issues associated with improved education, welfare, and other social services); Evolution of political orientations and policies (within and outside the sector); and Institutional/policy adaptations (such as economic liberalisation and deregulation, decentralisation, adherence to trading blocks, becoming parties to international agreements and the associated obligations).(FOSA,2010).

\section{Objective of the study}

The aim of the study was the assessment of ground carbon content for the three main specie (Acacia seyal, Acacia sengal and Balanites aegyptiaca ), as there were a number of global and national efforts to address the problem of Climate Change (CC) through adaptation and mitigation activities. Forests can and do play an important role in CC mitigation (Moomaw, et al. 2011).. So far, international debate has focused particularly on reducing emissions from deforestation and forest degradation in tropical developing countries. Content of ground carbon that was assessed would help tomitigate climate change through measures such as reducing deforestation and forest degradation, forest conservation, forest restoration and afforestation (US EIA,2007). Forest inventory was used through data as tool assessment of ground carbon content. (IPCC.2012). Using of inventory data to address natural forest condition and extended effort to climate change mitigation through carbon emission.The study area will represent oil industry activites within the state (Heiglig).

\section{Methodology}

The study area was conducted throughforest inventory cover area of 196.000 ha. It was located at South of Kordofan State (Heiglig). The main tree species were Acacia seyal, Acacia sengal and Balanites aegyptiaca. The natural forest has been actively managed for timber production, charcoal production and non-timber production like gum Arabic.

\section{Field data}

176 circular sample plots with dimater of $200 \mathrm{~m}^{2}$ were established randomly for field measurements of above ground biomass. The study area was stratified into three predefined forest types according to canopy density as recommendedby FAO 2002. (1) closed forest (2) open forest, (3) scatters trees and shrubs forest.This was done based on an existing stand map. We laid out plots in systematic grids in each stratum. Each plot centre was initially located in the field using 1:5000 topographic maps, and their positions were later determined accurately using Differential Global Positioning System (GPS) and Global Navigation Satellite System (GLONASS) having an accuracy of $<0.5 \mathrm{~m}$. The field inventory was carried out in the summer of 2012. The field inventory comprised recording of tree species, callipering of all trees with diameter at breast height $(\mathrm{dbh}) \geq 4 \mathrm{~cm}$, and height measurements with a Vertex hypsometer on sample trees selected with a probability proportional to stem basal area. The number of trees with height measurements ranged from 3 to 43 per plot with an average of 18 . Non-measured tree heights were later obtained from species specific diameterheight relationships. (Elsiddig, 2006).

Biomass and Carbon stock at the study area:

Result of the inventory conducted during period of March to April 2012 represented by table (1), (2) and (4). Dived into two part the biomass and dry matter of carbon content .

\section{Results}

\section{i.Biomass}

Table (1) provides inventory results and summaries of tree number (stocks per hectare) and average volume in cubic meter per tree and per hectare by forest cover categories. The process was completed to summarize total volume by forest cover category for the years 2012. (Tomppo, et al 2010).Harrison and Jackson (1958) described the area as belonging to the Acacia seyal- Balanites aegyptiaca savanna. The environment may be suitable for the growth and development of these two species that makes them the most dominant species in association defined in their namely (ibid).

Balanites aegyptiaca is characterized by its ability to reproduce by suckers. Off-springs developing from suckers grow fast and contribute in increasing the species percent share in the species composition (Brokensha and Riley 1980). It is known that species capable to develop through suckers increase the stand stock and the species share in the composition of savanna woodland .

However, Balanites aegyptiaca is also known to develop shoots after heavy browsing and hence has the ability to withstand heavy grazing and browsing as mentioned by key informant people of the area questioned through PRA, (Wani 2007). Acacia senegal on the other hand is fragile to heavy grazing by animals including wild rodents (Salaheldin, 1991). Wani (2007) mentioned that Acacia senegal is known for the local communities for production of gum arabic and for durable building poles and good quality fuel. That may be a strong reason that the local 
communities fell the Acacia senegal species for poles and fuel.

The results show that the Balanites aegyptiaca was one of the main species in the study area as closed forest, which equal to 53348.78ha. Acacia seyal is major species in study area as closed forest. However the Acacia sengal was found in small percentage in the closed forest category which confirms the description of (Herrison and Jakson, 1958) that shows the belt of Balanites aegyptiaca and Acacia seyal.

Using the method published by (Fang et al. 2001), forest inventory data, and parameters listed in Table 3, forest biomass (including all living trees and shrubs) Parameters used to calculate biomass expansion factor (BEF). ( Zhang. et al 2006) (BEF, defined as the ratio of all stand biomass to growing stock volume), which converts timber volume to carbon content value.

\section{ii.Carbon stock at the study area}

Conversion of volume stock to biomass and carbon stock changes were calculated following (Fang et al. 2001)using default Figure for conversion process. Table (4) shows the results of conversion from wet volume to dry mater and to carbon stock using (0.7975) as a default figure conversion factor for conversion of volume into dry biomass and for conversion of biomass into carbon content for tropical forest type.Coauthors, (2000) said that, carbon dioxide is incorporated into forests and forest soils by trees and other plants. Through photosynthesis, plants absorb carbon dioxide from the Earth's atmosphere.

A young forest, composed of growing trees, absorbs carbon dioxide and acts as a sink. Mature forests, made up of a mix of various aged trees as well as dead and decaying matter, may be carbon neutral above ground, (Ibid).

In the soil, however, the gradual build-up of slowly decaying organic material will continue to accumulate carbon, but at a slower rate than an immature forest. This accumulation of organic material in the form of (humus) in the forest floor only occurs below about 25 degrees Celsius,(IPCC, 2000). Above this temperature, humus is oxidized. Tropical jungles, for this reason, have very thin organic soils. The forest eco-system may eventually become carbon neutral. Forest fires release absorbed carbon back into the atmosphere.

\section{Discussion}

The disscussion will be divided into two catogreies, the first catogry had deal with the three species covering the study area at the South Kordfan State (Heglig area),second catogry haddeal with carbon content.

\section{Acacia seyal, Acacia sengal and Balanites aegyptiaca as indicators tools for climate change}

The three species that had been conducted within the inventory are Acacia seyal, Acacia sengal and Balanites aegyptiaca. However, ground survey involved tree species records and changes. The three main species included are Acacia seyal, Acacia sengal and Balanites aegyptiaca. The results show areas of regeneration potentials and gradual change of species composition the following stand development.The present study was providing a procedure for the evaluating direction of the trend of changes in forest and tree cover and their dynamics in relation to land use system in an important area in southern region of Sudan. As it has been possible to identify three categories of forest and tree cover, dynamic changes within and between these categories has been used in the context of addressing indicators as tools for monitoring changes. Most important is the use of indicators that address issues related to climate change. Deforestation in tropics constitutes one of the most important issues related to climate change.

\section{Carbon Storage in Trees related to study area.}

Moulton and Richards, (1990) said that estimates of growing-stock volume in a forest area were converted to estimates of carbon storage in trees in a two stage processes. First, growing-stock volume was estimated in terms of total forest tree volume by multiplying by a ratio to account for the additional tree volume excluded from estimates of growing-stock volume: tops and branches, foliage, rough and rotten trees, small trees, stump sections, roots, and bark. Ratios were derived from two principal sources, a new nationwide biomass. Containing the estimates of above-ground biomass by tree component (Cost et al .1990, Koch , 1989). Separate ratios were derived for each of the regions or climatic zones to account for different tree form and to be consistent with the data used to the growing-stock volume,(IPCC, 1996).

The present study provide used procedure to assess the ground carbon content for land cover using the forest inventory data were $(299118 \mathrm{~kg})$ of above ground carbon were obtain from 196000 ha from the rsult, however the amount of carbon would be indicator for climate change mitigation. Most important is the use of indicators that address issues related to climate change.(Fischlowitz. 2006)

\section{Carbon dioxide $\left(\mathrm{CO}_{2}\right)$ sinks realted to study area as} climate change indicator

A carbon dioxide $\left(\mathrm{CO}_{2}\right)$ sink is a carbon reservoir that is increasing in size, and is the opposite of a carbon dioxide "source". (Coauthors, 2000).the three main species in the study area Acacia seyal, Acacia sengal and Balanites aegyptiaca use photosynthesis to remove carbon from the atmosphere by incorporating it into biomass and release oxygen into the atmosphere. This concept of $\mathrm{CO}_{2}$ sinks has become more widely known because the Kyoto Protocol allows the use of carbon dioxide sinks as a form of carbon offset,The location and mechanisms responsible for the carbon sink in Sudan at south of kordofan state heiglig land are uncertain (total of $299118 \mathrm{~kg}$.). Here, we used an improved 
TABle 1. Sudan Land Cover Classes in Hectares*

\begin{tabular}{|c|c|c|}
\hline LAND COVER CLASS & AREA (HA) & $\%$ \\
\hline $\begin{array}{l}\text { AGRICULTURE IN TERRESTRIAL AND } \\
\text { AQUATIC/REGULARLY FLOODED LAND }\end{array}$ & $23,710,025$ & 12.6 \\
\hline $\begin{array}{l}\text { TREES CLOSED-TO-SPARSE IN TERRESTRIAL AND } \\
\text { AQUATIC/REGULARLY FLOODED LAND }\end{array}$ & $18,733,182$ & 10 \\
\hline $\begin{array}{l}\text { SHRUBS CLOSED-TO-SPARSE IN TERRESTRIAL AND } \\
\text { AQUATIC/REGULARLY FLOODED LAND }\end{array}$ & $22,231,327$ & 11.8 \\
\hline $\begin{array}{l}\text { HERBACEOUS CLOSED-TO-SPARSE IN TERRESTRIAL } \\
\text { AND AQUATIC/ REGULARLY FLOODED LAND }\end{array}$ & $25,982,720$ & 13.8 \\
\hline URBAN AREAS & 730,331 & 0.4 \\
\hline $\begin{array}{l}\text { BARE ROCKS AND SOIL AND/OR OTHER } \\
\text { UNCONSOLIDATED MATERIAL(S) }\end{array}$ & $95,277,727$ & 50.7 \\
\hline $\begin{array}{l}\text { SEASONAL/PERENNIAL, NATURAL/ARTIFICIAL } \\
\text { WATER BODIES }\end{array}$ & $1,290,000$ & 0.7 \\
\hline TOTAL SUDAN AREA & $187,955,312$ & 100 \\
\hline
\end{tabular}

*SOURCE: FAO, 2012: LAND COVER ATLAS OF SUDAN



Fig. 1. Sudan Land Cover 
TABLE (2): FOREST CLASSES OF STUDY AREA WITH THE AREAS AND CLASSIFICATION AND WOOD VOLUME .

\begin{tabular}{|l|l|l|l|l|l|}
\hline CATEGORIES OF FOREST & $\begin{array}{l}\text { AVERAGE } \\
\text { TREE } \\
\text { NUMBER } \\
\text { PER HA }\end{array}$ & $\begin{array}{c}\text { AVLUMEITREE } \\
\text { IN CU.M }\end{array}$ & $\begin{array}{c}\text { VOLUME PER } \\
\text { HA IN CU.M }\end{array}$ & $\begin{array}{c}\text { TOTAL } \\
\text { AREA PER } \\
\text { HA }\end{array}$ & $\begin{array}{l}\text { TOTAL } \\
\text { VOLUME } \\
\text { CU.M }\end{array}$ \\
\hline CLOSED FOREST CATEGORY & 140 & 0.75 & 105 & 82075 & 86180 \\
\hline WOODLAND CATEGORY & 70 & 0.45 & 31.5 & 51001 & 16065 \\
\hline $\begin{array}{l}\text { SCATTERED TREES AND SHRUBS } \\
\text { CATEGORY }\end{array}$ & 40 & 0.5 & 14 & 59209 & 10394 \\
\hline TOTAL & & & & 112639 \\
\hline
\end{tabular}

Table (3): wood volume according to inventory at the study area 2012

\begin{tabular}{|l|l|}
\hline Categories of forest & Volume cu.m(x 1000) \\
\hline Closed forest category & 86180 \\
\hline Open woodland category & 16065 \\
\hline Scattered trees and shrubs category & 10394 \\
\hline
\end{tabular}

Table (4): shows the Biomass Expansion Factor (BEF) for different types of forests.

\begin{tabular}{|c|c|}
\hline FOREST TYPE & $A\left(\mathrm{MG} \mathrm{M}^{-3}\right)$ \\
\hline POPULUS & 0.4754 \\
\hline TSUGA, CRYPTOMERIA, KETELEERIA & 0.4158 \\
\hline TROPICAL FORESTS & 0.7975 \\
\hline
\end{tabular}

Table (5) Volume of carbon content using (BEF) for the tropical forest.

\begin{tabular}{|l|l|l|}
\hline CATEGORIES OF FOREST & \multicolumn{1}{|c|}{$\begin{array}{c}\text { Volume in cu.m } \\
(\mathrm{X} 1000)\end{array}$} & CARBON CONTENT \\
\hline CLOSED FOREST CATEGORY & 86180 & 296505 \\
\hline OPEN WOODLAND CATEGORY & 16065 & 1892 \\
\hline SCATTERED TREES AND SHRUBS CATEGORY & 10394 & 721 \\
\hline TOTAL & & 299118 \\
\hline
\end{tabular}


estimation method of forest biomass through forest resource inventory in the area to estimate the amount in the storage of living biomass at 2012. (Kint. V et al 2012).

\section{Carbon sequestration and Forests as natural sequestration plants related to oil indutral area within thestudy area .}

The Heglig field is operated by Greater Nile Petroleum Operating Co (GNPOC), a consortium of Chinese, Malaysian, Indian and Sudanese companies. Producation of 70,000 bpd ).Coauthors (2001) said carbon sequestration is the term describing processes that remove carbon dioxide from the atmosphere. To help mitigate global warming, a variety of means of artificially capturing and storing carbon (while releasing oxygen) as well as of enhancing natural sequestration processes are being explored

Our results suggest that. Carbon storage increased significantly due to forest classification and species density, suggesting that carbon sequestration through forest management practices addressed in the Kyoto Protocol could help offset industrial carbon dioxide emissions. (K.P 11, 2005)

Gibbard et al. (2005) said that forests are carbon stores, and they are carbon dioxide sinks when they are increasing in density or area. Tropical reforestation can mitigate global warming until all available land has been reforested with mature forests, (IPCC 2007). Trees only cool the planet if they are planted in the tropics.William (2004), stated that in the United States the carbon dioxide is released mainly by combustion of fossil fuels (coal, oil and natural gas; and this adds great quantities to the atmosphere. The global cooling effect of carbon sequestration by forests is partially counterbalanced: For example, the planting of new forests may initially be a source of carbon dioxide emission when carbon from the soil is released into the atmosphere.

However, both processes of increase and decrease of carbon content contribute to climate change in two ways thus the study was clear the two ways within the three species. These processes result in the reduction of the green house gases sinks and at the same time play as source for green house gasses emissions as a result of burning of wood.(Ciais, P.etal 2008).

People relationship to land use and forests andunderstanding to forest cover change.

However, within the result of hunam acativity eithor tradtional or industerial, the dynamic changes which involve losses of forest cover associated with gains of forest cover indicate the need for understanding of the mechanisms that facilitate the gain so as to enhance more gain. The mechanism through which gain of forest cover is performed increases the chances for mitigation of greenhouse gas in the atmosphere. Forest cover gains take place through forest expansion that occurs as a result of regeneration processes whether natural or through artificial reforestation.(Emission factors IPCC 2012)

Recommendation :

\section{RECOMMENDATION :}

- A comprehensive land use / land cover plan for the study area is recommended to be carried.

- Above ground CARbon CONTENT MUST BE INVESTIGATED FOR OTHER LOCAL TREE SPECIES.

- AdDRESSING TO ClimATE CHANGE Mitigation WITH CARBON SINK AND EMISSION FOR NATURAL FOREST MANAGEMENT PRACTICE AT SUDAN.

- THE THE ABOVE GROUND CARBON CONTEND MUST BE CONCEDURE AS INVENTORY DATA TO BE USE AT SUDAN NATIONAL FOREST INVENTORY COUNTRY REPORT .

- $\quad$ OIL INDUSTRY AREA MUST BE UNDER PERIODICAL ENVIRONMENTAL CHECKING.

- CONTINUOUS FOREST INVENTORY By PERMANENT SAMPLE PLOTS

\section{References}

Brokensha D and Riley BW. 1980. Mbeere knowledge of their vegetation and its relevance for development: a case study from Kenya. In: Indigenous knowledge systems anddevelopment. D. Brokensha D, Warren DM and Werner O (eds.) Washington, DC: University Press of America.

Ciais, P. et al.2008. Carbon accumulation in European forests. Nature Geosci.1:1-5

Coauthors, 2000. The case of the missing sink, work publisher. April 20, 2000, url=http://www.mcgill $. \mathrm{ca} /$ reporter $/ 32 / 15 /$ roulet $/$ format $=\mid$ doi $=\mid$ accessdate $=$ $2007-02-23\}\}</$ ref $>$.

Coauthors, 2001. Sequestration of carbon by soil Soil Science . 166(11) : 858-871

Cost, N.D., Howard, J., Mead, B., McWilliams, W.H., S W.B., Van Hooser, D.D., Wharton, E.H. 1990. The biomass resource of the United States. U.S. Department of Agriculture, Forest Service, General Technical Report W0-57 Washington, DC. 21pp.

Elsiddig, E. A. 2006. Tree measurement in Sudan, University of Khartoum press: 159. 
Fang M, Jaffrey SR, Sawa A, Ye K, Luo X, Snyder SH.Neuron 2001. The Astrophysical Journal, 555:356-363

FAO, 2002. Global Forest Resources Assessment 2000, Main Report, FAO Forestry Paper \# 140, FAO of the United Nations, Rome, Italy.

Fischlowitz-R. B (2002). "Carbon Emissions Climbing". Earth Policy Institute. Retrieved 2006-08-12

FOSA 2010.The Forestry outlook paper for Sudan was carried out as part of a process to prepare the forestry outlook study for Africa towards 2020.

Gibbard, P. \& van Kolfschoten, Th. 2005 The Pleistocene and Holocene Series. 441-452. In: Gradstein, F. Ogg, J. \& Smith, A. (eds) A Geologic Time Scale 2004. Cambridge University Press 589 pp.

Harrison, N. N. and Jachson, J.K. 1953. Ecological classification of the vegetation of the Sudan. Khartoum, Ministry of Agriculture, Forest Bulletin No.2.

ICCP 2012,Emission Factor Database - Main Page. Retrieved 19 August 2012.

IPCC, 2000. National Greenhouse Gas Inventories Programme TSU Institute for Global Environmental Strategies 2108-11 Kamiyamaguchi, Hayama, Kanagawa 240-0115 Japan. E-mail: mail: http://www.ipcc-nggip.or.jp/mail

IPCC, 2007. Forestry In Climate Change 2007. Mitigation. Contribution of Working Group III to the Fourth Assessment Report of the Intergovernmental Panel on Climate Change, Nabuurs, G.J., O. Masera, K. Andrasko, P. Benitez-Ponce, R. Boer, M. Dutschke, E. Elsiddig, J. Ford-Robertson, P. Frumhoff, T.Karjalainen, O. Krankina, W.A. Kurz, M. Matsumoto, W. Oyhantcabal, N.H. Ravindranath, M.J. Sanz Sanchez, X. Zhang, 2007. CambridgeUniversity Press, Cambridge, United Kingdom and New York, NY, USA.

Kint, V. et al.2012. Radial growth change of temperate tree species in response to altered regional climate and air quality in the period 1901-2008. Climatic Change 115, 343-363 .

Koch, P. 1989. Estimates by species group and region in the USA of: I. Below-ground root weight as a percentage of ovendry complete-tree weight; and II. carbon content of tree portions. Consulting report. $23 \mathrm{pp}$.
Kyoto. Protocol 2005 international conference for climate change and mitigation.

Moomaw, W., P. Burgherr, G. Heath, M. Lenzen, J. Nyboer, A. Verbruggen, 2011. Annex II: Methodology. In IPCC: Special Report on Renewable Energy Sources and Climate Change Mitigation (ref. page 10)

Moran, E. and E. Brondizio. 1998. Land use Change After Deforestation in Amazonia. In: People and Pixels, D. Liverman, E. Moran, R. Rindfuss, and P. Stern 1998 (eds.). Washington, DC: National Academy Press.

Moulton, R. and K. Richards. 1990. Costs of Sequestration Carbon Through Tree Planting and Forest Management in the United States. U.S. Department of Agriculture Forest Service General Technical Report WO-58.

Salaheldin, G. H. 1991. Environmental degradation in Semi-arid rangeland in Northern Sudan. Desertification contra Bulletin No 19, (UNEP).

Tomppo, E., Gschwantner, T., Lawrence, M. \& McRoberts, R. E. (eds) National Forest Inventories Pathways for Common Reporting ,Springer, 2010.

UNFCCC 2005 Negotiations at 11th Conference of Parties (CoP 11) in Montreal in 2005.11th Conference of Parties (CoP 11) in Montreal.

US EIA, "Carbon intensity", International Energy Statistics, US Energy Information Administration (EIA), retrieved 21 December 2013. Archived page. Public-domain source: 'U.S. Government publications "Source: U.S. Energy Information Administration (Oct 2008)."'

Wani SP, Sahrawat KL, Sreedevi TK, Bhattacharyya T and Ch.Sreenivasa Rao. 2007. Carbon sequestration in the semi-arid tropics for improving livelihoods. International Journal of Environmental Studies, Vol. 64, No. 6, December 2007. 719-727

Williams, J. R, 2004. Addressing global warming and biodiversity through forest restoration and coastal weltlands creation. Science of The Total Environment 240, 1-9.

Zhang. X, Roman. M, Kimmel. D, McGilliard. $\mathrm{C}$ and Boicourt. W. 2006. Spatial variability in plankton biomass and hydrographic variables along an axial transect in Chesapeake Bay. Journal of Geophysical Research. 111. 1-16. 